\title{
Geranium pamiricum Ikonn. (Geraniaceae): systematics and chorology
}

\author{
Viktoriya I. Troshkina ${ }^{1 *}$, and Khukhuu Enkhtuvshin ${ }^{2}$ \\ ${ }^{1}$ Central Siberian Botanical Garden,630090 Novosibirsk, Russian Federation \\ ${ }^{2}$ Plant Protection Research Institute of Mongolia, 17024 Ulaanbaatar, Mongolia
}

\begin{abstract}
This article addresses specific features of morphology and chronology of a species found for the first time in the flora of the Altai highland: Geranium pamiricum Ikonn. It is demonstrated that the species under study belongs to the taxon G. collinum Steph. ex Willd. A nomenclature citation is provided with a mention of type specimens and their storage locations and ecological confinedness. A key was compiled for identification of species of the section Recurvata. Issues of chronology are discussed, and a map of this species' geographic range is provided.
\end{abstract}

\section{Introduction}

This article continues a series of publications about the genus Geranium L. (Geraniaceae Juss.) in the Altai highland. While researching the genus Geranium, we found several new taxa on this territory. One of such species is G. pamiricum Ikonn., described by V.V. Ikonnikov [1] in the paper "Notes on the flora of Badashkhan and Pamir." This species belongs to the taxon G. collinum Steph. ex Willd. and is a member of one of the most difficult-to-study sections of the genus: Recurvata (Knuth) Novosselova. On the one hand, the independence of this species is beyond any doubt; on the other hand, it can sometimes be found in herbarial collections under the name $G$. collinum.

After the study on this species in the wild and critical examination of herbarial material, it was necessary to conduct a comparative analysis of morphological traits, ecological confinedness, and features of geographic occurrence for finding clear-cut diagnostic features. The text below provides a nomenclature citation, typification evidence, and data on the geographic range and ecology as well as notes; a map of the areal was composed and a key was compiled for identifying species of the section Recurvata. Chronology within the Altai highland is also given according to the zoning of "Altai Flora" [2].

\section{Materials and methods}

The species in question was observed in the wild on the territory of the Republic of Tajikistan and was studied in herbaria of V.L. Komarov Botanical Institute of the Russian

\footnotetext{
*Corresponding author: vitroshkina@csbg.nsc.ru
} 
Academy of Sciences (LE), Moscow State University (MW), N.V. Tsytsin Main Botanical Garden (MHA), and the Botanical Institute of the Tajik Academy of Sciences (TAD). The material for the comparative morphological analysis of traits consisted of samples from herbarial collections of LE, MW, and TAD and photographic material from the Herbarium at the Institute of Biology of the National Academy of Sciences of the Kyrgyz Republic (FRU). The measurement of characteristics of the lamina was done directly in a herbarium, without removal of the samples. Specimens of seeds were taken from the herbarium at LE.

Investigation of the surface of fruits and seeds was carried out under a scanning electron microscope (Carl Zeiss EVO MA 10) in the Central Siberian Botanical Garden, the Siberian Branch of the Russian Academy of Sciences. The fruits and seeds were attached to the microscope stage with an adhesive tape, then gold was sputtered by means of a Mini SC 7620 device, followed by scanning. A map of the areal was created by the point contact method in the SimpleMappr software (http://www.simplemappr.net).

\section{Results and discussion}

The species G. pamiricum belongs to the section Recurvata of subsection Collina Knuth. The main diagnostic features of the section are petal length $(15-25 \mathrm{~mm})$ and the shape and degree of division of the lamina (into 5-7 wide rhombic lobes). The morphological traits include dimensions of a pollen grain $(68-111 \times 65-108 \mu \mathrm{m})$. Diagnostic features at the subsection level are the corolla shape (balloonflowerlike), corolla color (from pink to violet, rarely albino), calyx lobe length $(6-8 \mathrm{~mm})$, and lamina width of lower cauline leaves (3-9 cm). The morphological traits include specific features of ornamentation of the pollen grain surface (pollen grain with $2-5$ obtuse longitudinal tips with a papillose surface without transverse stripes, less often with transverse stripes). On the Altai highland territory, the subsection Collina, aside from $G$. pamiricum includes two more species: $G$. collinum and G. saxatile Kar. et Kir. (Table 1).

Table 1. Diagnostic features of species in the genus Geranium of subsection Collina in the section Recurvata.

\begin{tabular}{|c|c|c|c|}
\hline \multirow{2}{*}{ Feature } & \multicolumn{3}{|c|}{ Species name } \\
\hline & G. collinum & G. saxatile & G. pamiricum \\
\hline $\begin{array}{l}\text { Type of leaf } \\
\text { pubescence }\end{array}$ & $\begin{array}{l}\text { Uniformly diffused; on } \\
\text { lamina lower side: } \\
\text { mostly on veins }\end{array}$ & $\begin{array}{l}\text { Scarce, diffused, mostly } \\
\text { on veins on both sides of } \\
\text { lamina }\end{array}$ & $\begin{array}{l}\text { Scarce, mostly on veins; } \\
\text { leaves are glabrescent on } \\
\text { both sides of lamina }\end{array}$ \\
\hline $\begin{array}{l}\text { Width of apical } \\
\text { lobules of leaves, } \\
\mathrm{mm}\end{array}$ & $4-8$ & $3-5$ & $1.5-3.5$ \\
\hline $\begin{array}{l}\text { Type of mericarp } \\
\text { pubescence }\end{array}$ & $\begin{array}{l}\text { Consisting of simple } \\
\text { conical, threadlike, } \\
\text { compound conical } \\
\text { multicellular and } \\
\text { unicellular glandular } \\
\text { filaments }\end{array}$ & $\begin{array}{l}\text { Consisting of simple } \\
\text { conical, threadlike } \\
\text { multicellular or } \\
\text { unicellular glandular } \\
\text { filaments }\end{array}$ & $\begin{array}{l}\text { Consisting of simple } \\
\text { conical, threadlike, } \\
\text { compound conical } \\
\text { unicellular glandular } \\
\text { filaments }\end{array}$ \\
\hline Seed shape & $\begin{array}{l}\text { Ellipsoid rounded-- } \\
\text { quadrangular with keel }\end{array}$ & $\begin{array}{l}\text { Ellipsoid rounded-- } \\
\text { quadrangular with keel }\end{array}$ & Ellipsoid with keel \\
\hline Seed size, $\mathrm{mm}$ & $2.5-3.5$ & $3-4$ & $1.7-2.2$ \\
\hline
\end{tabular}


The main diagnostic features of $G$. pamiricum are as follows: pubescence types of leaves and mericarps, width of apical lobules of leaves, and the shape and size of the seed (Fig. 1).


Fig. 1. Seeds and mericarps of species in the genus Geranium of the section Recurvata (subsection Collina). Panels 1 and 4: G. collinum; 2 and 5: G. saxatile; 3 and 6: G. pamiricum.

According to several studies $[1,3,4]$, the areal of $G$. pamiricum encompasses the Pamir Mountains, Tien Shan, and North and West Kashgaria. While studying the herbarial samples, we found specimens of G. pamiricum from the territory of Mongol Altai, where this species has never been registered (Fig. 2). The big gap in the geographic range may be explained by a lack of scientific studies on the highland territories.



Fig. 2. The general map of G. pamiricum general distribution (scale: 1:300).

According to the studied materials, the species grows under the conditions of middle mountains and highlands at absolute heights of 1100-3900 (4150) $\mathrm{m}$ above the sea level. It occurs in meadow communities, often in sedge-Cobresia groupings, sometimes subsalsuginous meadows. The nomenclature citation of $G$. pamiricum follows. 
G. pamiricum Ikonn. 1972, Nov. Syst. Plant. Vasc. 9: 301; Shibkova, Kizinkaeva, 1981, in Fl. Tadzh. SSR, 6: 346; Nabiev, 1983, Conspectus florae Asiae Mediae, 7: 11, Novosselova, 1996, Botanicheskii Zhurnal, 81(10): 88.

Described in Tajikistan (Badakhshan) ("Habitat in pratis subalpinis"). Holotype et Isotype: "Tadzh. SSR, Gorno-Badakhshan Autonomous Region. Sarez Lake vicinity. North shore. Vikhtonlakht valley, grassplot with Mentha asiatica, eastern exposure, at exit of groundwater. 3350 m, 16 VIII 1958, № 8743, Coll. S. Ikonnikov. Det. S. Ikonnikov” (LE!).

On protologue: "Tadshikistania, Badachschan, lacus Sarezicus, vallis Vichtonlacht, in pratis, 3350 m s. m., 16 VIII 1958, № 8743, S. Ikonnikov. - Tadzh. SSR, Badakhshan, north shore of Sarez Lake, Vikhtonlakht valley, on grassplot with Mentha asiatica Boriss., 3350 m above sea level. 16 VIII 1958, № 8743, S.S. Ikonnikov (LE).”

On highland grassplots, along creeks, on lake shores in upper altitudinal zone in mountains.

Altai highland. (KAD9) (Mongolian People's Republic, Kobdoss aimak, 7 km south of Bulgan village, meadow on bank of progressively overgrown channel in ancient valley of Bulgan River, $1100 \mathrm{~m}$ below sea level, № 5078, 15 VIII 1982, I.A. Gubanov). General distribution: Kashgaria: north, west; Dzungaria: Tien Shan; Pamir Mountains.

The key to the species of subsection Collina of the genus Geranium from the Altai highland

1. Stems are weak, ascendant or almost erect; laminae of lower cauline leaves are deeply (up to $3 / 4$ or more) are divided into 5-7 almost rhombic lobes, pinnatisect into 3-5 oviform-lanceolate or lance-shaped segments or large denticles.

+ Erect stems, laminae of lower cauline leaves are somewhat divided into 5 widerhombic lobes, trisected into cuneiform-reverse-oviform lobules, usually

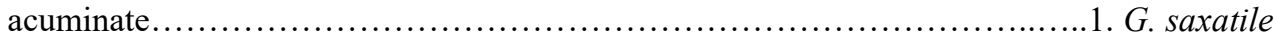

2. Laminae of cauline leaves are divided into 5-7 lobes, are uniformly pubescent, width of apical lobules of leaves $4-8 \mathrm{~mm}$, seeds $2.5-3.5 \mathrm{~mm}$ long.................. . G. collinum

+ Laminae of cauline leaves are divided into 5 lobes, pubescence scarce, almost absent, width of apical lobules of leaves 1.5-3.5 mm, seeds 1.7-2.2 $\mathrm{mm}$ long 3. G. pamiricum

Thus, in this G. pamiricum study in the wild and in herbarial collections, this species was for the first time found in the flora of the Altai highland. The comparative analysis of species traits in the subsection Collina, which includes the analyzed species, indicates that its main diagnostic features are the pubescence type of lamina and mericarps, width of apical lobules of leaves, and the shape and size of the seed. The main part of the $G$. pamiricum areal is concentrated in the Pamir and Tien Shan Mountains. The big disjunction is explained probably by the lack of scientific studies on the highland territories of the intermediate regions.

The authors are deeply grateful to S.V. Ovchinnikova and Yu.V. Ovchinnikov for the help with obtaining photos from the herbarium of FRU. The English language was corrected and certified by shevchuk-editing.com. This work was done within the framework of the state assignment of the Central Siberian Botanical Garden (the Siberian Branch of the Russian Academy of Sciences) on topic AAAA-A17-117012610055-3 "Biological Diversity of Cryptogamic Organisms (Algae, Fungi, and Lichens) and Vascular Plants in the Geospace of Biotic and Abiotic Factors and Their Role in Aquatic and Terrestrial Ecosystems of North Asia."

\section{References}

1. S.S. Ikonnikov, Nov. Syst. Plant. Vasc., 9 (1972). 
2. R.V. Kamelin, Flora of Altai (Azbuka, Barnaul, 2005).

3. M.M. Nabiev, Geranium, in Consp. Fl. Aziae Mediae, 7 (Academiae scientiarum UzSSR, 1983).

4. M.S. Novosselova, Bot. Zh., 81, 10 (1996).

5. I.F. Shibkova, G.K. Kizinkaev, Geranium, in Flora Tadzhikskoy SSR, 6 (Nauka, Leningrad, 1981). 